\title{
NEW RECORDS AND LIST OF KNOWN SPECIES OF THE FAMILY DOLICHOPODIDAE (DIPTERA, EMPIDOIDEA) FROM CROATIA
}

\author{
Mihail Kechev \& Mariyana Ivanova \\ University of Agribusiness and Rural Development, 78 Dunav Blvd., Plovdiv 4003, Bulgaria \\ (e-mails: mkechev@gmail.com, mivanova@vard.bg)
}

Kechev, M. \& Ivanova, M.: New records and list of known species of the family Dolichopodidae (Diptera, Empidoidea) from Croatia. Nat. Croat., Vol. 24, No. 2, 323-330, 2015, Zagreb

Two dolichopodid species (Rhaphium caliginosum Meigen and Medetera jacula (Fallén)) are recorded for the first time in Croatia. With these new data the total number of dolichopodid flies in Croatia is 38, which are listed here.

Key words: Croatia, Dolichopodidae, Rhaphium caliginosum, Medetera jacula, biodiversity

Kechev, M. \& Ivanova, M.: Novi nalazi i popis vrsta porodice Dolichopodidae (Diptera, Empidoidea) za Hrvatsku. Nat. Croat., Vol. 24, No. 2, 323-330, 2015, Zagreb

Dvije vrste dugonogih muha (Rhaphium caliginosum Meigen i Medetera jacula (Fallén)) zabilježene su po prvi puta za Hrvatsku. S tim nalazima ukupni broj vrsta dugonogih muha za Hrvatsku iznosi 38 te rad donosi popis tih vrsta.

Ključne riječi: Hrvatska, Dolichopodidae, Rhaphium caliginosum, Medetera jacula, bioraznolikost

\section{INTRODUCTION}

The family Dolichopodidae is one of the largest families of the suborder Brachycera (order Diptera) with more than 7400 representatives from all over the world (PAPE et al. 2009; Grichanov et al., 2011).

The dolichopodid fauna of Croatia is poorly investigated and majority of records are from the second half of the 19th and in the first half of the 20th century. Strobl (1900) published a book for the territory of Bosnia, Herzegovina and Dalmatia and listed 20 dolichopodid flies from Croatia (Dalmatia). Some new dolichopodids were described from Croatia as well. Mıк (1889) described Sciapus [Psilopus] lesinensis Mik, 1889 from Lesina Island, Dalmatia (now Hvar Island). PARENT (1927) described Lamprochromus dalmaticus Parent, 1927 from Dubrovnik (Ragusa) and afterwards in 1932 the same author described Sciapus oldenbergi Parent, 1932 from Učka Mountain (Istria). PARent (1938) mentioned eight dolichopodids distributed in Croatia (Dalmatia).

More recently, Pollet (2011) in the Fauna Europaea database listed several dolichopodids and the total number of species for Croatia raised to 36.

\section{MATERIAL AND METHODS}

The additional material was collected by sweep net from two different sites in Croatia (Fig. 1) - an irrigation canal in the town of Križevci $\left(46^{\circ} 00^{\prime} 14^{\prime \prime} \mathrm{N} 16^{\circ} 32^{\prime} 16^{\prime \prime} \mathrm{E}, 121\right.$ 

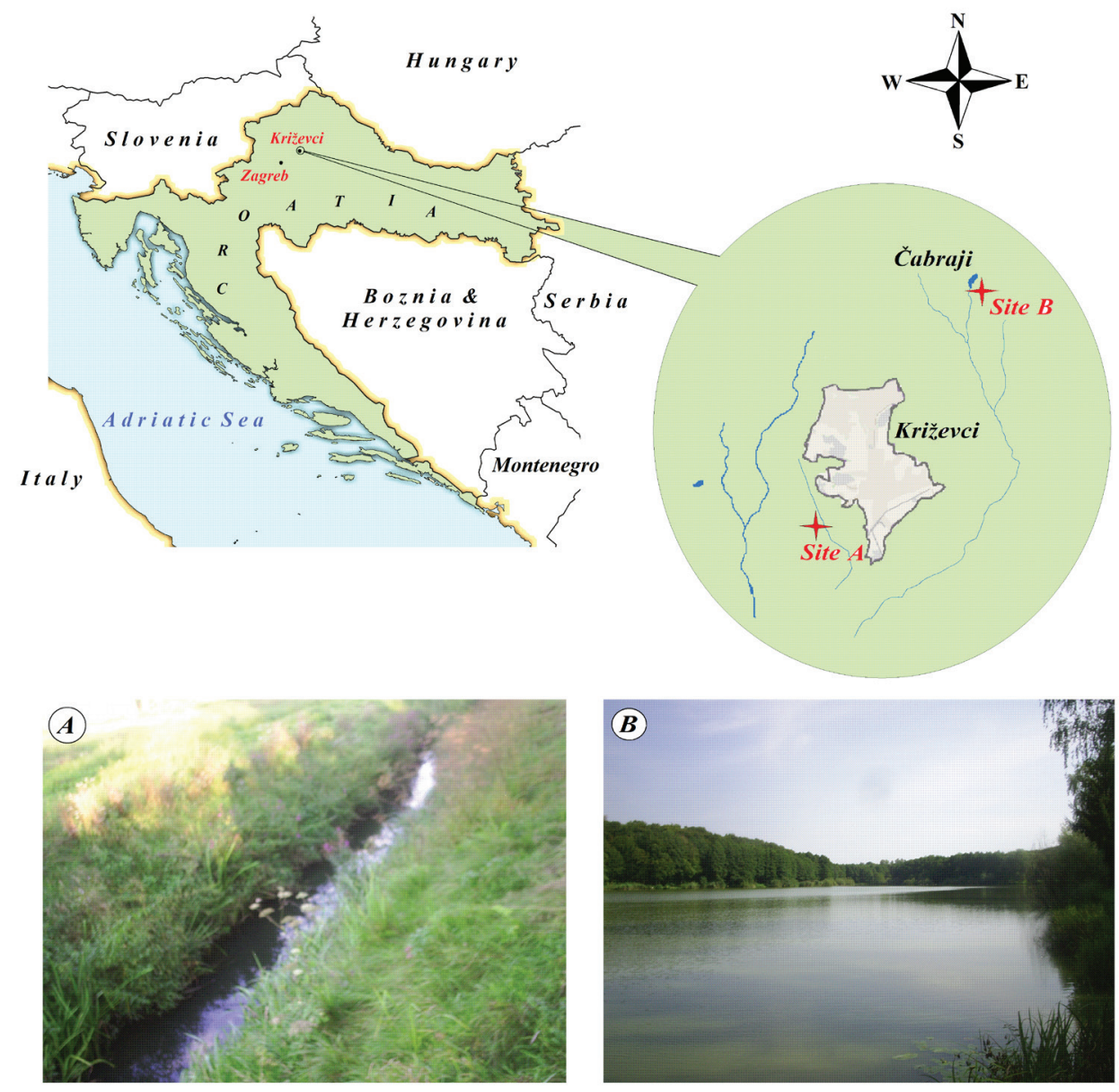

Fig. 1. Map of Croatia with collecting sites - Site A. Irrigation canal in the town of Križevci, Site B. Reservoir Čabraji (drawing and photos M. Kechev).

$\mathrm{m}$ a.s.1.) and the Reservoir Čabraji ( $46^{\circ} 05^{\prime} 46^{\prime \prime} \mathrm{N} 16^{\circ} 35^{\prime} 07^{\prime \prime} \mathrm{E}, 165 \mathrm{~m}$ a.s.1.) near the village of Čabraji.

Diptera collected in the field were placed in 70\% ethanol. Specimens were sorted in the laboratory using a Konus 5420 Diamond microscope. Identification keys by PARENT (1938), Negrobov \& Stackelberg (1969), Grichanov (2007) were used for the identification of the species new to Croatia.

\section{RESULTS}

The following format is used for the literature records given below: name of the site (citation of reference); and for new records: Croatian province, name of the site, the sampling date, number of sampled specimens per sex, collector. 


\section{Subfamily DIAPHORINAE}

Genus Argyra Macquart, 1834

1. Argyra argyria (Meigen, 1824)

Croatia (Pollet, 2011);

Genus Chrysotus Meigen, 1824

2. Chrysotus cupreus (Macquart, 1827)

Croatia (POLLET, 2011);

3. Chrysotus palustris Verrall, 1876

Croatia (Pollet, 2011);

4. Chrysotus suavis Loew, 1857

Dubrovnik (Ragusa) and Split (Spalato) (SтroвL, 1900);

\section{Subfamily DOLICHOPODINAE}

\section{Genus Dolichopus Latreille, 1796}

5. Dolichopus plumipes (Scopoli, 1763)

Croatia (Pollet, 2011);

6. Dolichopus signifer Haliday, 1832

Dubrovnik (Ragusa) (Strobl, 1900);

7. Dolichopus strigipes Verrall, 1875

Ston (Italian: Stagno; near Dubrovnik (BECKER, 1889) (as D. aratriformis); Dalmatia (Croatia) (Parent, 1938);

\section{Genus Hercostomus Loew, 1857}

8. Hercostomus chetifer (Walker, 1849)

Island Hvar (Lesina, Dalmatia) (SтrовL, 1900);

9. Hercostomus fuscipennis (Meigen, 1824)

Istria (Croatia) (PARENT, 1938);

10. Hercostomus longiventris (Loew, 1857)

Dalmatia (Croatia) (PARENT, 1938);

11. Hercostomus lorifer Mik, 1878

Croatia (Dalmatia) (PArent, 1938), (Pollet, 2011);

12. Hercostomus vivax (Loew, 1857)

Croatia (Dalmatia) (PArent, 1938), (Pollet, 2011);

Genus Ortochile Latreille, 1809

13. Ortochile nigrocoerulea Latreille, 1809

Dubrovnik (Ragusa), Zadar (Zara) and Split (Spalato) (STroвL, 1900) Dubrovnik, Dalmatia (Croatia) (PArent, 1938), Croatia (Pollet, 2011);

Genus Sybistroma Meigen, 1824

14. Sybistroma inornata (Loew, 1857)

Dubrovnik (Ragusa) (Strobl, 1900); Croatia (Dalmatia) (Parent, 1938; Pollet, 2011); 


\section{Subfamily HYDROPHORINAE}

Genus Aphrosylus Haliday, 1851

15. Aphrosylus piscator Lichtwardt, 1902

Croatia (Pollet, 2011);

16. Aphrosylus venator Loew, 1857

Dubrovnik (Ragusa) (Strobl, 1900);

Genus Hydrophorus Fallén, 1823

17. Hydrophorus praecox (Lehmann, 1822)

Croatia (Dalmatia) (Strobl, 1900);

Genus Machaerium Haliday, 1832

18. Machaerium thinophilum (Loew, 1857)

Croatia (Pollet, 2011);

\section{Genus Thinophilus Wahlberg, 1844}

19. Thinophilus flavipalpis (Zetterstedt, 1843)

Zadar (Zara), on the sea shore (SтRовL, 1900);

20. Thinophilus ruficornis (Haliday, 1838)

Croatia (Dalmatia) (SтRовL, 1900);

\section{Subfamily MEDETERINAE}

Genus Medetera Fischer von Waldheim, 1819

21. Medetera diadema (Linnaeus, 1767)

Zadar (Zara) (SтRовL, 1900);

22. Medetera flavipes Meigen, 1824

Zadar (Zara) (SтRовL, 1900);

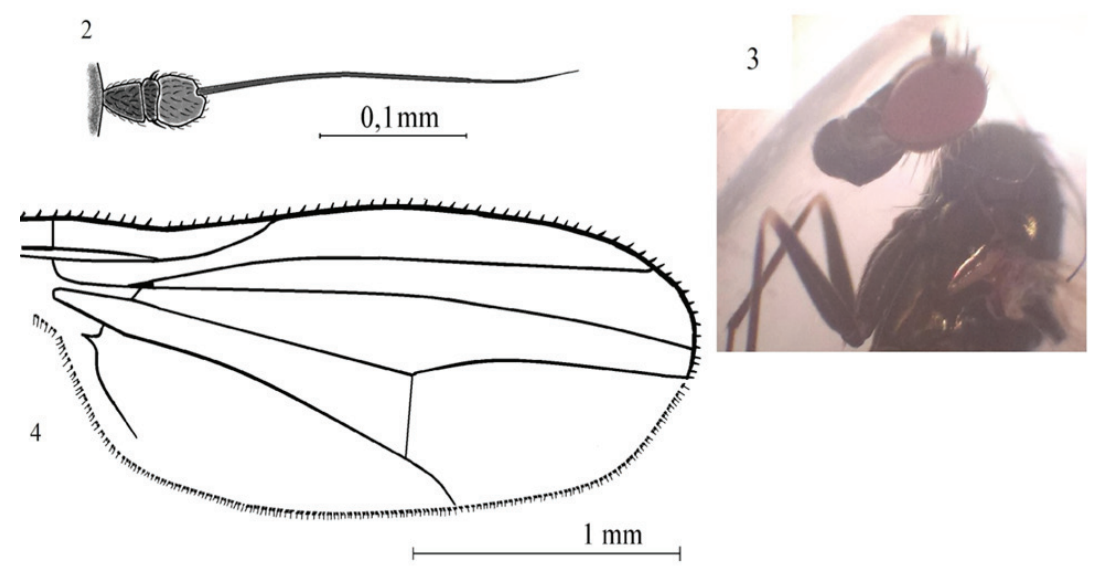

Figs 2-4. Medetera jacula (Fall.), male: 2. antenna; 3. head, thorax and fore legs; 4.wing; (photo and drawings M. Kechev). 
23. Medetera glaucella Kowarz, 1877

Dubrovnik (Ragusa), on the sea rocks (Strobl, 1900), Croatia (Dalmatia) (PArent, 1938), Croatia (Pollet, 2011);

24. Medetera jacula (Fallen, 1823) New to Croatia. Figs. 2-4.

Material examined: Koprivnica-Križevci County, on the banks of the Reservoir Čabraji, 31.VIII.2014, 1ð, 1ㅇ, leg. M. Kechev.

25. Medetera micacea Loew, 1857

Croatia (Dalmatia) (SтrовL, 1900);

26. Medetera truncorum Meigen, 1824

Šibenik (Sebenico) (Strobl, 1900), Croatia (Pollet, 2011);

Genus Systenus Loew, 1857

27. Systenus bipartitus (Loew, 1850)

Croatia (Pollet, 2011);

Genus Thrypticus Gerstaecher, 1864

28. Thrypticus bellus Loew, 1869

Dubrovnik (Ragusa) (StroвL, 1900);

29. Thrypticus smaragdinus Gerstacker, 1864

Croatia (Pollet, 2011);

\section{Subfamily NEURIGONINAE}

Genus Neurigona Rondani, 1856

30. Neurigona nubifera (Loew, 1869)

Dubrovnik (Ragusa) (Strobl, 1900);

\section{Subfamily PELOROPEODINAE}

\section{Genus Micromorphus Mik, 1878}

31. Micromorphus albipes (Zetterstedt, 1843)

Šibenik (Sebenico) (STrobL, 1900);

\section{Subfamily RHAPHIINAE}

Genus Rhaphium Meigen, 1803

32. Rhaphium caliginosum Meigen, 1824 New to Croatia. Figs. 5-7.

= Rhaphium zetterstedti (Parent, 1925)

Material examined: Koprivnica-Križevci County, Križevci, irrigation canal, 30. VIII.2014, 1万̄, leg. M. Kechev.

\section{Subfamily SCIAPODINAE}

Genus Sciapus Zeller, 1842

33. Sciapus contristans (Wiedemann, 1817)

Dubrovnik (Ragusa) (Sтroвl, 1900);

34. Sciapus lesinensis (Mik, 1889)

Island Hvar, Croatia (Lesina, Dalmatia) (Mıк, 1889); 


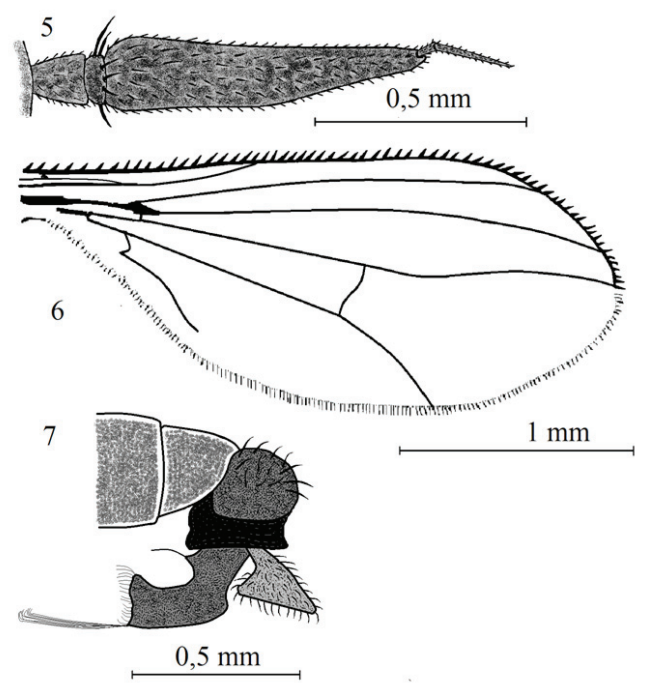

Figs 5-7. Rhaphium caliginosum Meig., male: 5. antenna, 6. wing, 7. hypopygium; (drawings M. Kechev).

\section{Sciapus oldenbergi Parent, 1932}

Učka Mountain (Istria) (PARENT, 1932);

36. Sciapus pallens (Wiedemann, 1830)

Island Hvar, Croatia (Isl. Lesina, Dalmatia) (Strobl, 1900); Croatia (Pollet, 2011);

\section{Subfamily SYMPYCNINAE}

\section{Genus Lamprochromus Mik, 1878}

37. Lamprochromus dalmaticus Parent 1927

Dubrovnik (Ragusa) (Parent, 1927); Croatia (Pollet, 2011);

\section{Genus Syntormon Loew, 1857}

\section{Syntormon pallipes (Fabricius, 1794)}

Dubrovnik (Ragusa), Island Hvar (Island Lesina) and Zadar (Zara) (StroвL, 1900).

\section{DISCUSSION AND CONCLUSION}

In 1889 Becker published a new species from Dalmatia - Dolichopus aratriformis, synonym of Dolichopus strigipes Verrall 1875. Checking the current literature about the distribution of Dolichopodidae (Pollet, 2011; Grichanov, 2014), the authors gave D. strigipes as doubtful for Croatia. Having in mind that BECKER gave clear description of the species and drawing of the hypopygium of D. strigipes (described as D. aratriformis), we consider this species is present in the fauna of Croatia and we added it to the list of known species.

These new data increase the number of known dolichopodid species for the fauna of Croatia to 38 . 


\title{
ACKNOWLEDGEMENTS
}

The present paper is dedicated to the senior author's great grandfather Jacob Mihailov Shtrok (1900 - 1948) who was born in Zagreb, Croatia. Thanks are due to all scientists and lecturers from Agricultural College in Križevci (Croatia). The visit to Croatia was supported by the grant of the European program "Erasmus +".

Received May 7, 2015

\section{REFERENCES}

BeCKeR, T. 1889: Neue Dipteren aus Dalmatien. Berliner Entomologische Zeitschrift 33, 335-346.

Grichanov, I. YA., 2007: A checklist and keys to Dolichopodidae (Diptera) of the Caucasus and East Mediterranean. St. Petersburg: VIZR RAAS, Plant Protection News Suppl., pp. 1-160.

Grichanov, I.YA., 2014: Alphabetic list of generic and specific name of predatory flies of the epifamily Dolichopodoidae (Diptera), St.Petersburg: VIZR, 544 p. (»Plant Protection News, Supplements», N14).

Grichanov, I.Ya., O.V. Selivanova \& O. P. Negrobov, 2011: A brief synopsis of Palaeartic genera of the family Dolichopodidae (Diptera). Ukrainska Entomofaunistyka 2(2), 11-40.

Мıк, J., 1889: Zur Kenntniss der Dolichopodiden (Dipt.). Wiener Entomologische Zeitung 8, 305 pp.

Negrobov, O. P., \& A. A. Stackelberg, 1969: Faune des Dolichopodidae. - In: Opredeliteli nasekomych evropeiskoi ciasti SSSR. Leningrad, Dvukrylye, blokhi, 5(1), 670-752. (In Russian).

PAPE, T., Bickel, D. \& MeIER, R., 2009: Diptera Diversity: Status, Challenges and Tools. (Koninklijke Brill NV: Leiden.) $459 \mathrm{pp}$.

PARENT, O., 1927: Dolichopodides paléarctiques nouveaux ou peu connus. Enc. Ent., Sér. B II Dipt. 4, 45-96.

PAREnT, O., 1932: Sur quelques Dipteres Dolichopodides, la plupart appurtenant a la collection L. Oldenberg notes et descriptions (Dipt). Stettin ent Ztg 93, 220-241.

Parent, O., 1938: Diptères Dolichopodidés. Fauna de France, 35. L'Académie des Sciences de Paris, Paris, $720 \mathrm{pp}$.

Pollet, M., 2011: Fauna Europaea: Dolichopodidae. In: PAPE, T. \& Beuk, P. (Eds.), Fauna Europaea: Diptera, Brachycera. Fauna Europaea version 2.4, http://www.faunaeur.org. [accessed on 20 December 2013].

StroвL, G., 1900: Dipterenfauna von Bosnien, Hercegovina und Dalmatien. Mitteilungen aus Bosnien und Hercegovina 7, $550-670$.

\section{SUMMARY}

\section{New records and list of known species of the family Dolichopodidae (Diptera, Empidoidea) from Croatia}

\author{
M. Kechev \& M. Ivanova
}

In the present paper we give information about two new dolichopodid flies (Rhaphium caliginosum Meig. and Medetera jacula Fall.) in the fauna of Croatia. A list of 36 species belonging to 18 genera were known for Croatia until now (Argyra argyria, Chrysotus cupreus, Ch. palustris, Ch. suavis, Dolichopus plumipes, D. signifer, D. strigipes, Hercostomus chetifer, $H$. fuscipennis, H. longiventris, H. lorifer, H. vivax, Ortochile nigrocoerulea, Sybistroma inornata, Aphrosylus piscator, A. venator, Hydrophorus praecox, Machaerium thinophilum, Thinophilus flavipalpis, Th. ruficornis, Medetera diadema, M. flavipes M. glaucella, M. micacea, M. truncorum, Systenus bipartitus, Thrypticus bellus, Th. smaragdinus, Neurigona nubifera, Sciapus contristans, S. lesinensis, S. oldenbergi, Sciapus pallens, Lamprochromus dalmaticus, Micromorphus albipes, Syntormon pallipes). With these new data the total number of known Dolichopodidae species for Croatia increases to 38 . 
